\title{
SHBG and total testosterone levels in men with adult onset hypogonadism: what are we overlooking?
}

\author{
Stephen J. Winters (10
}

\begin{abstract}
Background: Adult onset male hypogonadism $(\mathrm{AOH})$ is a common clinical condition whose diagnosis and management are controversial, and is often characterized by a low level of SHBG, but our understanding of why testosterone levels are low when SHBG is low is incomplete.

Methods: This retrospective chart review was performed to compare the relationship between SHBG and testosterone in the plasma of men presenting for evaluation of $\mathrm{AOH}$ with a cohort of men treated chronically with transdermal testosterone.

Results: The level of SHBG was $<30 \mathrm{nmol} / \mathrm{L}$ in $73 \%$ of men who presented for evaluation of $\mathrm{AOH}$, and was inversely proportional to BMI in both the untreated and the testosterone-treated men. As in previous populations, the level of SHBG was highly positively correlated $(r=0.71, p<0.01)$ with the total testosterone level in untreated men presenting for evaluation of $\mathrm{AOH}$, but no relationship was found between the level of SHBG and total testosterone among men who were being treated with a transdermal testosterone preparation.

Conclusions: These findings further support the idea that SHBG regulates testicular negative feedback either directly or by modulating the entry of testosterone or estradiol into cells in the hypothalamus and/or pituitary to control gonadotropin synthesis and secretion which explains in part the low testosterone levels in men with $\mathrm{AOH}$.
\end{abstract}

Trial registration: Not applicable

Keywords: SHBG, Testosterone, Male hypogonadism, Metabolic syndrome

\section{Background}

Adult onset male hypogonadism (AOH) is a clinical condition characterized by symptoms consistent with androgen deficiency together with a consistently low total testosterone level that is not explained by classical disorders of the hypothalamus-pituitary or the testis [1]. Its diagnosis and management remain controversial [2, 3]. Many men given this diagnosis have a low level of sex hormone-binding globulin (SHBG) associated with

Correspondence: Stephen.Winters@louisville.edu

Division of Endocrinology, Metabolism and Diabetes, University of Louisville, ACB-A3G11, 550 Jackson Street, Louisville, KY 40202, USA obesity, type 2 diabetes (T2DM), dyslipidemia and nonalcoholic fatty liver disease (NAFLD).

SHBG is a homodimeric glycoprotein, and both monomers can bind sex steroids $[4,5]$. The binding affinity of SHBG for testosterone is high, and has been reported to vary across total testosterone levels [6], and to demonstrate allosteric interaction between the two binding sites [7]. Thus, it follows that the level of SHBG, which binds testosterone with high affinity and transports testosterone in the circulation, is strongly positively correlated with the level of testosterone in plasma [8, 9].

What is unclear is whether the low testosterone level in men with $\mathrm{AOH}$ is due solely to less circulating SHBG

(c) The Author(s). 2020 Open Access This article is licensed under a Creative Commons Attribution 4.0 International License, which permits use, sharing, adaptation, distribution and reproduction in any medium or format, as long as you give appropriate credit to the original author(s) and the source, provide a link to the Creative Commons licence, and indicate if changes were made. The images or other third party material in this article are included in the article's Creative Commons licence, unless indicated otherwise in a credit line to the material. If material is not included in the article's Creative Commons licence and your intended use is not permitted by statutory regulation or exceeds the permitted use, you will need to obtain permission directly from the copyright holder. To view a copy of this licence, visit http://creativecommons.org/licenses/by/4.0/ The Creative Commons Public Domain Dedication waiver (http://creativecommons.org/publicdomain/zero/1.0/) applies to the data made available in this article, unless otherwise stated in a credit line to the data. 
or whether additional mechanisms are involved. A long-standing idea is that increased estradiol production in $\mathrm{AOH}$ suppresses $\mathrm{GnRH}-\mathrm{LH}$ secretion and testosterone biosynthesis. In support of this idea, many men with $\mathrm{AOH}$ are overweight, aromatase is expressed in subcutaneous adipose tissue [10], and estradiol levels are often increased in obese men [11, 12]. However, not all data support this notion. For example, estradiol levels did not correlate inversely with testosterone with increasing obesity [13]. Moreover, total and calculated free estradiol levels were lower, rather than higher, among men with T2DM with low total and calculated free testosterone levels, when compared to values among diabetic men with normal total and free testosterone [14]. Furthermore, in the European Male Aging Study, men diagnosed with late onset hypogonadism, with lower testosterone and SHBG levels and a higher waist circumference and BMI than the eugonadal men, also had lower estradiol levels [15]. A second idea is that elevated proinflammatory cytokines, such as TNF $\alpha$ and interleukins, suppress $\mathrm{GnRH}$ and testicular steroidogenesis. In this regard, when interleukin-2 was administered iv to men, testosterone levels declined but LH levels were unchanged [16]. Third, leptin activates kisspeptin neurons to stimulate GnRH [17], and leptin deficiency is associated with hypogonadotropic hypogonadism [18]. Moreover, leptin treatment restores the testosterone deficiency that occurs with fasting [19]. As obese individuals are viewed as resistant to leptin, leptin resistance may also play a role in $\mathrm{AOH}$.

Another possible explanation is that variation in SHBG, either directly or through free testosterone and/or estradiol levels, regulates GnRH-LH and thereby testosterone and estradiol secretion until a new equilibrium is reached $[20,21]$. In support of this idea, deRonde et al. [22] found a positive association between SHBG and testosterone in newborn boys in whom the GnRH pulse generator is active, as in adult men, but this relationship is absent among prepubertal boys age 5-8 yrs [23] whose GnRH pulse generator is suppressed, and is negligible in umbilical cord blood [24]. Furthermore, SHBG levels are inversely related to testosterone in normal pre- and post-menopausal women [25] among whom testosterone is not viewed as an important regulator of GnRH-LH secretion. If SHBG regulates LH secretion and contributes to the strong positive correlation between circulating SHBG and testosterone levels in men, the relationship should be present in untreated men with $\mathrm{AOH}$ whose hypothalamic-pituitary-testis is functional, but may be attenuated or absent in testosterone -treated men. This retrospective analysis was conducted in order to explore this hypothesis.

\section{Methods}

Medical records were reviewed retrospectively from adult men who presented for a clinical evaluation of adult onset hypogonadism $(n=33)$, and from adult men who were being treated for hypogonadism with transdermal testosterone $(n=25)$.

The men with $\mathrm{AOH}$ presented for evaluation because of erectile dysfunction, low libido and/or asthenia. A thorough medical history and physical examination were performed, and classical causes of hypogonadism were excluded, in most cases by additional endocrine testing. Testis size was $\geq 20 \mathrm{~mL}$. 6 men had diabetes, and 16 were being treated for dyslipidemia.

Testosterone-treated men had been diagnosed with adult onset hypogonadism $(n=12)$, hypopituitarism $(n=$ 9), congenital hypogonadotropic hypogonadism $(n=2)$, or Klinefelter syndrome $(n=2)$, and were being treated with a stable dose of a transdermal testosterone preparation.

Assays were performed at Quest Diagnostics. Testosterone levels were measured by liquid chromatographymass spectrometry, and SHBG was measured by immunoassay. Free testosterone was measured by indirect equilibrium dialysis. Laboratory reference ranges for adult men are: $250-1100 \mathrm{ng} / \mathrm{dL}$ for total testosterone, $10-50 \mathrm{nmol} / \mathrm{L}$ for SHBG, and $35-155 \mathrm{pg} / \mathrm{mL}$ for free testosterone.

\section{Statistical analysis}

Two group comparisons were performed using Student's t-test or the Mann-Whitney Rank Sum test when data were not normally distributed or groups had unequal variance. Pearson correlation coefficients were calculated using SigmaStat/Systat Software, Inc. (San Jose, CA). Data are presented as the mean \pm SD or the median and $25-75 \%$ range.

\section{Results}

The characteristics of the patient groups are summarized in Table 1. Of the 33 men seeking an evaluation for hypogonadism, 7 men had a total testosterone level below the assay reference range $(<250 \mathrm{ng} / \mathrm{dL}$, $8.68 \mathrm{nmol} / \mathrm{L})$ and 14 were below $300 \mathrm{ng} / \mathrm{dL}$ $(10.4 \mathrm{nmol} / \mathrm{L})$, a level which is often selected as the threshold to diagnose testosterone deficiency [26]. Only one man had a free testosterone level below the reference range $(35-155 \mathrm{pg} / \mathrm{ml})$. Testosterone-treated men were older $(p=0.002)$ and had a lower BMI $(p=$ 0.04) than the men with AOH. Among the testosterone- treated men, total testosterone levels were within the reference range in $22 / 24$.

As summarized in Table 2, those men in the $\mathrm{AOH}$ cohort with a total testosterone level $<300 \mathrm{ng} / \mathrm{dL}$ were similar in age to those with a normal total testosterone 
Table 1 Clinical characteristics for men presenting for evaluation and treatment of adult onset hypogonadism, and men treated chronically with transdermal testosterone

\begin{tabular}{llll}
\hline & $\begin{array}{l}\text { Adult onset hypogonadism } \\
(\boldsymbol{n}=\mathbf{3 3})\end{array}$ & $\begin{array}{l}\text { T-treated hypogonadal men } \\
(\boldsymbol{n}=\mathbf{2 5})\end{array}$ & $\begin{array}{c}\boldsymbol{P} \text { value } \\
\text { Age }(\mathrm{yrs})\end{array}$ \\
BMI $\left(\mathrm{kg} / \mathrm{m}^{2}\right)$ & $45(31.5-55.0)^{\mathrm{a}}$ & $61.0(48.0-67.5)$ & .002 \\
Testosterone $(\mathrm{ng} / \mathrm{dL})$ & $32.0(27.8-39.3)$ & $29.1(24.6-33.1)$ & .04 \\
SHBG $(\mathrm{nmol} / \mathrm{L})$ & $317(237-391)$ & $452(360-528)$ & .001 \\
Free testosterone $(\mathrm{pg} / \mathrm{mL})$ & $25.7(21.2-35.0)$ & $31.0(22.5-40.5)$ & .189 \\
\hline
\end{tabular}

To convert total testosterone levels to $\mathrm{nmol} / \mathrm{L}$ multiply by 0.0347

Median $(25-75 \%)$

concentration, but had a higher BMI $(p=0.002)$ and a lower level of SHBG $(p=0.002)$. SHBG was $<20 \mathrm{nmol} / \mathrm{L}$ in 9 men, and was $<30 \mathrm{nmol} / \mathrm{L}$ in 24 of the men $(73 \%)$ who presented for evaluation of $\mathrm{AOH}$.

The level of SHBG was inversely proportional to BMI in both the untreated and the testosterone-treated men (Fig. 1). The relationship between SHBG and total testosterone is shown for the untreated and T-treated men in Fig. 2. As in previous analyses of results in eugonadal men $[8,9,22]$, the level of SHBG is highly positively correlated $(r=0.71, p<0.01)$ with the total testosterone level in untreated men who presented for evaluation of $\mathrm{AOH}$. On the other hand, there is no significant relationship between the levels of SHBG and total testosterone among men who were being treated with a transdermal testosterone preparation (Fig. 2).

\section{Discussion}

The findings of this study provide further support for the idea that the mechanism for the strong positive correlation between the circulating levels of SHBG and total testosterone in men is more complex than the stoichiometry of a high affinity circulating transport protein which controls metabolic clearance, and its ligand. Instead, the positive correlation in untreated, but not in testosterone-treated men, implies that SHBG regulates testicular negative feedback either directly or by modulating the entry of testosterone or estradiol into cells in the hypothalamus and/or pituitary to control gonadotropin synthesis and secretion, and thereby testosterone levels.
An effect of SHBG on gonadotropin and sex steroid secretion is implied from observations in men with hyperthyroidism who typically have high serum levels SHBG as well as LH and testosterone [27, 28]. Likewise, SHBG as well as LH and testosterone levels increased when normal men were rendered hyperthyroid by thyroxine administration [29], and normalize when hyperthyroid men become euthyroid [28]. These findings are likely explained by the effect of thyroxine to increase SHBG mRNA levels by stimulating the transcription factor hepatocyte nuclear factor $4 \alpha(\mathrm{HNF} 4 \alpha)$ [30] that activates the SHBG promoter [31].

The concept that a circulating high affinity binding protein regulates hypothalamic-pituitary function also follows from the changes that occur in hypothyroid women who become pregnant. During pregnancy, there is a twofold increase in circulating thyroglobulin levels due to the effect of increased placental estrogens [32, 33]. TSH levels rise, but thyroid dysfunction prevents the normal compensatory increase in thyroid hormone synthesis, and TSH remains elevated. Therefore, the thyroxine dose is generally increased in hypothyroid women during pregnancy.

Despite some inconsistent findings, estradiol negative feedback remains an attractive potential explanation for the low testosterone level in $\mathrm{AOH}$. Many studies have shown that much of the testicular negative feedback control of gonadotropin secretion in men is through estradiol. When estradiol is infused iv at physiological levels, LH is suppressed [34, 35]. SERMs with antiestrogenic effects in the CNS increase circulating LH as well

Table 2 Characteristics of men presenting for evaluation and management of $\mathrm{AOH}$

\begin{tabular}{llll}
\hline & $\begin{array}{l}\text { Low testosterone } \\
(\boldsymbol{n}=\mathbf{1 4})\end{array}$ & $\begin{array}{l}\text { Normal testosterone } \\
(\boldsymbol{n}=\mathbf{1 9})\end{array}$ & $\begin{array}{c}\boldsymbol{P} \text { value } \\
\text { Testosterone }(\mathrm{ng} / \mathrm{dL})\end{array}$ \\
Age $(\mathrm{yrs})$ & $253(191-285)^{\mathrm{a}}$ & $350(320-439)$ & .001 \\
$\mathrm{BMI}\left(\mathrm{kg} / \mathrm{m}^{2}\right)$ & $42.0(33.8-56.0)$ & $45.0(29.0-53.0)$ & .72 \\
SHBG $(\mathrm{nmol} / \mathrm{L})$ & $37.4 \pm 7.1$ & $30.2 \pm 5.8$ & .002 \\
Free testosterone $(\mathrm{pg} / \mathrm{mL})$ & $21.5(12.7-25.0)$ & $33.0(24.0-42.0)$ & .002 \\
\hline
\end{tabular}

To convert total testosterone levels to $\mathrm{nmol} / \mathrm{L}$ multiply by 0.0347

${ }^{a}$ Median (25-75\%) or mean \pm SD 

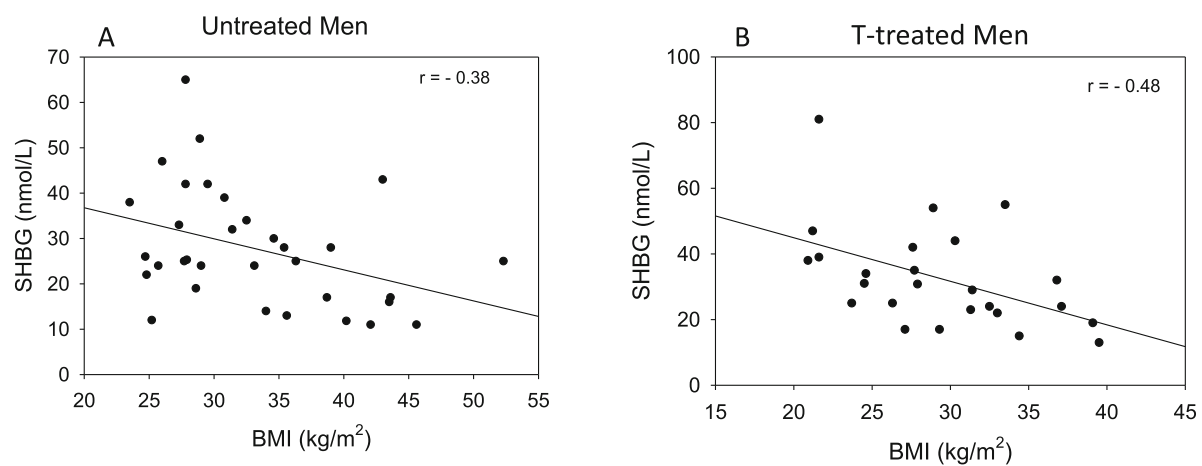

Fig. 1 Relationship between BMI and SHBG in untreated men who presented for evaluation of $A O H(\mathbf{a})$ and a cohort of men who were being treated with a transdermal testosterone preparation (b). In a) BMI $=38.808-(0.206 *$ SHBG; $r=-0.38, p=0.032$, and b) $\mathrm{BMI}=33.352-(0.0755 *$ SHBG); $r=-0.48, p=0.05$

as testosterone levels in normal men [36, 37], as do aromatase inhibitors $[38,39]$. Furthermore, men with inactivating mutation of the aromatase gene often have high $\mathrm{LH}$ and testosterone levels [40]. The measurement approaches for free and/or non-SHBG testosterone levels continue to be debated [41, 42], and quantification of non-SHBG-bound estradiol is even more challenging. Total estradiol levels in normal men are $<1 \%$ of total testosterone levels, and accurate measurement requires LC-MS methodology [43]. For free estradiol, even direct assay by LC-MS following dialysis of the plasma sample will be problematic since the value may be $2-3 \%$ [44] of $20-30 \mathrm{pg} / \mathrm{mL}$, or $<1 \mathrm{pg} / \mathrm{mL}$. Results of previous studies in which free or bioavailable estradiol levels were determined by immunoassays or by calculation, and were related to testosterone in $\mathrm{AOH}$ and other outcomes, will need to be confirmed.

SHBG levels are often decreased in men who present for evaluation of $\mathrm{AOH}[45,46]$. In this study, 13/14 untreated men with a testosterone level of $<300 \mathrm{ng} / \mathrm{dL}$ had an SHBG level of $<30 \mathrm{nmol} / \mathrm{L}$, and increased BMI predicted lower SHBG levels in not only untreated but also testosterone-treated men. These observations support the importance of metabolic regulation of SHBG, and underscore the need to measure SHBG in the clinical evaluation of men with suspected $\mathrm{AOH}$ in order to identify those who are at increased risk for Metabolic Syndrome, T2DM, NAFLD and cardiovascular disease.

This is a provocative but limited study. Limitations include a relatively small sample size, and not all T-treated men had AOH. Only one blood sample was obtained. Finally, the cross-sectional analysis does not provide further insight into why some adult men develop low SHBG levels. These observations may, however, encourage a rethinking and further studies into the link between SHBG and testosterone in AOH.

\section{Conclusions}

The level of SHBG is low in most men presenting for evaluation of $\mathrm{AOH}$. There is a strong positive correlation between the levels of SHBG and total testosterone among untreated men with $\mathrm{AOH}$ but not in
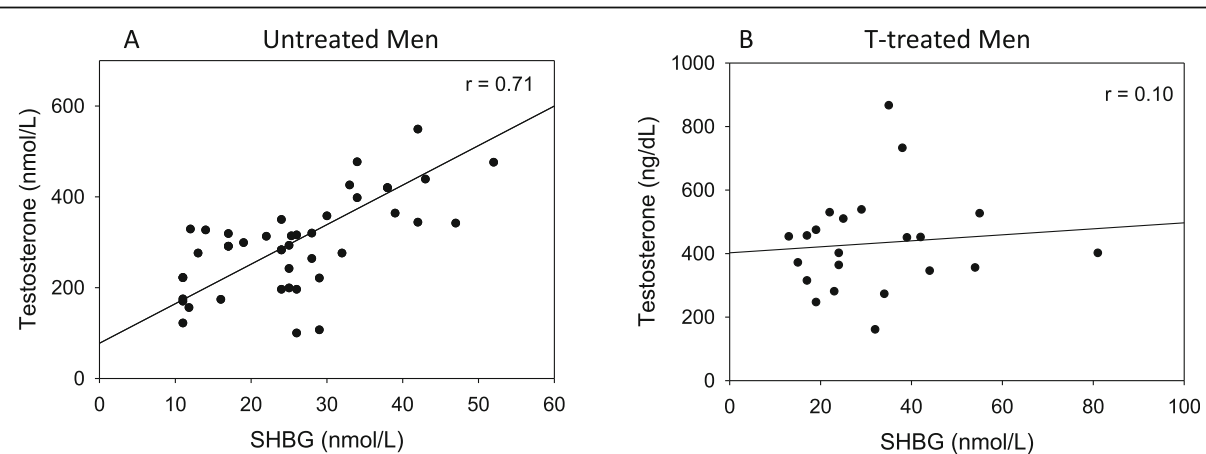

Fig. 2 Relationship between the plasma levels of SHBG and total testosterone among men presenting for evaluation of $A O H$ (a) and a cohort of men who were being treated with a transdermal testosterone preparation $(\mathbf{b})$. In $\mathbf{a}$, testosterone $=77.532+(8.709 *$ SHBG $), r=0.71, p<0.01$, and in b) testosterone $=371.209+(2.023 * \mathrm{SHBG}) ; r=0.1, p=0.16$ 
testosterone-treated men. This finding implies that SHBG regulates testosterone production through a negative feedback mechanism either directly or by modulating the entry of testosterone or estradiol into cells in the hypothalamus and/or pituitary. Measuring SHBG is helpful in understanding the pathophysiology and in management decisions for men with $\mathrm{AOH}$.

\section{Abbreviations}

AOH: Adult onset hypogonadism; BMI: Body mass index; LC-MS: Liquid chromatography-mass spectroscopy; LH: Luteinizing hormone; SERM: Selective estrogen response modifiers; NAFLD: Non-alcoholic fatty liver disease; T2DM: Type-2 diabetes mellitus; SHBG: Sex hormone-binding globulin; T: Testosterone; TSH: Thyroid stimulating hormone

\section{Acknowledgements}

None

\section{Author contributions}

SJW conducted the chart review and prepared the manuscript. The author(s) read and approved the final manuscript.

\section{Funding}

This research was supported in part by the Walter F. and Avis Jacobs Foundation.

\section{Availability of data and materials}

Data are available upon request.

\section{Ethics approval and consent to participate}

This research was based on a retrospective chart review, and was designated as Exempt.

\section{Consent for publication}

Not applicable.

\section{Competing interests}

None.

Received: 11 May 2020 Accepted: 21 September 2020

Published online: 29 September 2020

\section{References}

1. Khera M, Broderick GA, Carson CC 3rd, Dobs AS, Faraday MM, Goldstein I, et al. Adult-onset hypogonadism. Mayo ClinProc. 2016;91(7):908-26.

2. Rastrelli G, Carter EL, Ahern T, Finn JD, Antonio L, O'Neill TW, et al. Development of and recovery from secondary hypogonadism in aging men: prospective results from the EMAS. J ClinEndocrinolMetab. 2015;100(8): 3172-82.

3. Yeap BB, Grossmann M, McLachlan RI, Handelsman DJ, Wittert GA, Conway $A J$, et al. Endocrine Society of Australia position statement on male hypogonadism (part 2): treatment and therapeutic considerations. Med J Aust. 2016;205(5):228-31

4. Hammond GL. Plasma steroid-binding proteins: primary gatekeepers of steroid hormone action. J Endocrinol. 2016;230(1):R13-25.

5. Goldman AL, Bhasin S, Wu FCW, Krishna M, Matsumoto AM, Jasuja R. A reappraisal of testosterone's binding in circulation: physiological and clinical implications. Endocr Rev. 2017:38(4):302-24.

6. Avvakumov GV, Grishkovskaya I, Muller YA, Hammond GL. Resolution of the human sex hormone-binding globulin dimer interface and evidence for two steroid-binding sites per homodimer. J BiolChem. 2001;276(37): 34453-7.

7. Zakharov MN, Bhasin S, Travison TG, Xue R, Ulloor J, Vasan RS, et al. A multistep, dynamic allosteric model of testosterone's binding to sex hormone binding globulin. Mol Cell Endocrinol. 2015:399:190-200.

8. Vermeulen A, Kaufman JM, Giagulli VA. Influence of some biological indexes on sex hormone-binding globulin and androgen levels in aging or obese males. J ClinEndocrinolMetab. 1996;81(5):1821-6.
9. Winters SJ, Kelley DE, Goodpaster B. The analog free testosterone assay: are the results in men clinically useful? ClinChem. 1998:44(10):2178-82.

10. Zhao Y, Nichols JE, Bulun SE, Mendelson CR, Simpson ER. Aromatase P450 gene expression in human adipose tissue Role of a Jak/STAT pathway in regulation of the adipose-specific promoter. J BiolChem. 1995;270(27): 16449-57.

11. Schneider G, Kirschner MA, Berkowitz R, Ertel NH. Increased estrogen production in obese men. J ClinEndocrinolMetab. 1979;48(4):633-8.

12. Kley HK, Edelmann P, Krüskemper HL. Relationship of plasma sex hormones to different parameters of obesity in male subjects. Metabolism. 1980;29(11): 1041-5.

13. Giagulli VA, Kaufman JM, Vermeulen A. Pathogenesis of the decreased androgen levels in obese men. J ClinEndocrinolMetab. 1994;79(4):997-1000.

14. Dhindsa S, Furlanetto R, Vora M, Ghanim H, Chaudhuri A, Dandona P. Low estradiol concentrations in men with subnormal testosterone concentrations and type 2 diabetes. Diabetes Care. 2011;34(8):1854-9. .

15. Tajar A, Huhtaniemi IT, O'Neill TW, Finn JD, Pye SR, Lee DM, et al. Characteristics of androgen deficiency in late-onset hypogonadism: results from the European Male Aging Study (EMAS). J ClinEndocrinolMetabol. 2012;97(5):1508-16.

16. Veldhuis J, Yang R, Roelfsema F, Takahashi P. Proinflammatory cytokine infusion attenuates LH's feedforward on testosterone secretion: modulation by age. J ClinEndocrinolMetab. 2016;101(2):539-49.

17. Roseweir AK, Millar RP. The role of kisspeptin in the control of gonadotrophin secretion. Hum Reprod Update. 2009;15(2):203-12.

18. Farooqi IS, Jebb SA, Langmack G, Lawrence E, Cheetham CH, Prentice AM, et al. Effects of recombinant leptin therapy in a child with congenital leptin deficiency. N Engl J Med. 1999;341(12):879-84.

19. Chan JL, Heist K, DePaoli AM, Veldhuis JD, Mantzoros CS. The role of falling leptin levels in the neuroendocrine and metabolic adaptation to short-term starvation in healthy men. J Clin Invest. 2003;111(9):1409-21.

20. Rosner $\mathbf{W}$. The functions of corticosteroid-binding globulin and sex hormone-binding globulin: recent advances. Endocr Rev. 1990;11(1):80-91. .

21. de Ronde W, van der Schouw YT, Muller M, Grobbee DE, Gooren LJ, Pols $\mathrm{HA}$, et al. Associations of sex-hormone-binding globulin (SHBG) with nonSHBG-bound levels of testosterone and estradiol in independently living men. J ClinEndocrinolMetab. 2005;90(1):157-62.

22. de Ronde $W$, van der Schouw YT, Pierik FH, Pols HA, Muller M, Grobbee DE, et al. Serum levels of sex hormone-binding globulin (SHBG) are not associated with lower levels of non-SHBG-bound testosterone in male newborns and healthy adult men. ClinEndocrinol. 2005;62(4):498-503.

23. Aydın B, Winters SJ. Sex hormone-binding globulin in children and adolescents. J Clin Res PediatrEndocrinol. 2016;8(1):1-12.

24. Keelan JA, Mattes E, Tan H, Dinan A, Newnham JP, Whitehouse AJ, et al. Androgen concentrations in umbilical cord blood and their association with maternal, fetal and obstetric factors. PLoS ONE. 2012; 7(8):e42827

25. Pasquali R, Macor C, Vicennati V, Novo F, De lasio R, Mesini $P$, et al. Effects of acute hyperinsulinemia on testosterone serum concentrations in adult obese and normal-weight men. Metabolism. 1997:46(5):526-269.

26. Salter CA, Mulhall JP. Guideline of guidelines: testosterone therapy for testosterone deficiency. BJU Int. 2019:124(5):722-9. .

27. Kidd GS, Glass AR, Vigersky RA. The hypothalamic-pituitary-testicular axis in thyrotoxicosis. J ClinEndocrinolMetab. 1979:48(5):798-802.

28. Hudson RW, Edwards AL. Testicular function in hyperthyroidism. J Androl. 1992;13(2):117-24.

29. Ruder H, Corvol P, Mahoudeau JA, Ross GT, Lipsett MB. Effects of induced hyperthyroidism on steroid metabolism in man. J ClinEndocrinolMetab. 1971;33(3):382-7.

30. Selva DM, Hammond GL. Thyroid hormones act indirectly to increase sex hormone-binding globulin production by liver via hepatocyte nuclear factor-4alpha. J MolEndocrinol. 2009;43(1):19-27.

31. Janne M, Hammond GL. Hepatocyte nuclear factor-4 controls transcription from a TATA-less human sex hormone-binding globulin gene promoter. J BiolChem. 1998:273(51):34105-14.

32. Glinoer $D$, de Nayer $P$, Bourdoux $P$, Lemone $M$, Robyn $C$, van Steirteghem $A$ et al. Regulation of maternal thyroid during pregnancy. J ClinEndocrinolMetab. 1990;71(2):276-87.

33. Ain $\mathrm{KB}$, Mori $Y$, Refetoff $S$. Reduced clearance rate of thyroxine-binding globulin (TBG) with increased sialylation: a mechanism for estrogen-induced 
elevation of serum TBG concentration. J ClinEndocrinolMetab. 1987;65(4): 689-96.

34. Sherins RJ, Loriaux DL. Studies of the role of sex steroids in the feedback control of FSH concentrations in men. J ClinEndocrinolMetab. 1973;36(5): 886-93.

35. Santen RJ. Is aromatization of testosterone to estradiol required for inhibition of luteinizing hormone secretion in men? I Clinlnvestig. 1975; 56(6):1555-63.

36. Winters SJ, Janick JJ, Loriaux DL, Sherins RJ. Studies on the role of sex steroids in the feedback control of gonadotropin concentrations in men. II. Use of the estrogen antagonist, clomiphene citrate. J ClinEndocrinolMetab. 1979;48(2):222-7.

37. Winters SJ, Troen P. Evidence for a role of endogenous estrogen in the hypothalamic control of gonadotropin secretion in men. J ClinEndocrinolMetab. 1985:61(5):842-5.

38. Hayes FJ, Seminara SB, Decruz S, Boepple PA, Crowley WF Jr. Aromatase inhibition in the human male reveals a hypothalamic site of estrogen feedback. J ClinEndocrinolMetab. 2000;85(9):3027-35.

39. Marynick SP, Loriaux DL, Sherins RJ, Pita JC Jr, Lipsett MB. Evidence that testosterone can suppress pituitary gonadotropin secretion independently of peripheral aromatization. J ClinEndocrinolMetab. 1979;49(3):396-8.

40. Morishima A, Grumbach MM, Simpson ER, Fisher C, Qin K. Aromatase deficiency in male and female siblings caused by a novel mutation and the physiological role of estrogens. J ClinEndocrinolMetab. 1995;80(12):3689-98.

41. Keevil BG, Adaway J. Assessment of free testosterone concentration. J Steroid BiochemMolBiol. 2019;190:207-11.

42. Handelsman DJ. Free testosterone: pumping up the tires or ending the free ride? Endocr Rev. 2017;38(4):297-301.

43. Kushnir MM, Rockwood AL, Yue B, Meikle AW. High sensitivity measurement of estrone and estradiol in serum and plasma using LC-MS/MS. Methods MolBiol. 2010;603:219-28.

44. Dunn JF, Nisula BC, Rodbard D. Transport of steroid hormones: binding of 21 endogenous steroids to both testosterone-binding globulin and corticosteroid-binding globulin in human plasma. J ClinEndocrinolMetab. 1981;53(1):58-68.

45. Grossmann M. Hypogonadism and male obesity: focus on unresolved questions. ClinEndocrinol. 2018;89(1):11-21.

46. Jarecki P, Herman WA, Pawliczak E, Lacka K. Can low SHBG serum concentration be a good early marker of male hypogonadism in metabolic syndrome? Diabetes MetabSyndrObes. 2019;12:2181-91.

\section{Publisher's Note}

Springer Nature remains neutral with regard to jurisdictional claims in published maps and institutional affiliations.

Ready to submit your research? Choose BMC and benefit from:

- fast, convenient online submission

- thorough peer review by experienced researchers in your field

- rapid publication on acceptance

- support for research data, including large and complex data types

- gold Open Access which fosters wider collaboration and increased citations

- maximum visibility for your research: over $100 \mathrm{M}$ website views per year

At $\mathrm{BMC}$, research is always in progress.

Learn more biomedcentral.com/submissions 